\title{
HAART with Hydroxyurea and Didanosine
}

National Cancer Institute

\section{Source}

National Cancer Institute. HAART with Hydroxyurea and Didanosine. NCI Thesaurus.

Code C157540.

Treatment for human immunodeficiency virus (HIV) infection that uses a combination of the antiretroviral drugs hydroxyurea and didanosine. The drugs inhibit the ability of the virus to multiply in the body, and they slow down the development of AIDS. 